\title{
Temporal analysis of water volume at Capoeira Reservoir Mãe d'Água, Paraíba, Brazil
}

\section{Análise temporal do volume de água da Barragem Capoeira, Município de Mãe d'Água, Paraíba}

\author{
Denize Monteiro dos Anjos ${ }^{1 *}$; Danilo de Medeiros Arcanjo Soares ${ }^{2}$; Ewerton Medeiros Simões ${ }^{3}$; Ana Claudia Caetano \\ Pinheiro Leite ${ }^{4}$; Talytta Menezes Ramos ${ }^{5}$; Ivonete Alves Bakke
}

\begin{abstract}
The "Polígono das Secas" is a region in the Northeast of Brazil that stands out by its low precipitation, high temperatures, and dry climate. Geoprocessing and the remote sensing techniques used in this research demonstrate the effectiveness for the monitoring of environmental resources. The objective of this work was to use the normalized difference water index (NDWI) in a comparative analysis of the reduction of the water surface area of the dry periods, November 2009 and December 2016, of the Capoeira Reservoir using images from the Landsat 5 TM satellite and Landsat 8 OLI, respectively. The results showed high values of NDWI in 2009, corresponding to La Niña period, with high precipitation and overflow of reservoirs. NDWI values in 2016 were low due to the low precipitations typical of El Niño periods. NDWI can be used to detect and monitor the presence of water and is an excellent tool to assist water monitoring agencies through the monitoring of rivers, lakes, and reservoirs in regions as the northeastern of Brazil.
\end{abstract}

Key words: Water resources; Geoprocessing; Remote sensing; Semi-arid

Resumo: O Polígono da Seca é uma região no Nordeste que se destaca por apresentar baixa precipitação, altas temperaturas e clima seco. As ferramentas do geoprocessamento e as técnicas de sensoriamento remoto podem ser utilizadas para demonstrarem a efetividade para o monitoramento de recursos ambientais. O objetivo foi utilizar o índice de diferença normalizada da água (NDWI) em uma análise comparativa da redução da área do espelho d'água dos períodos seco, novembro de 2009 e dezembro de 2016 da barragem Capoeira a partir das imagens do satélite Landsat 5 TM e Landsat 8 OLI., obtidas no site do Serviço Geológico dos Estados Unidos (USGS. Os resultados da comparação entre os anos apresentam altos valores de NDWI em 2009, o que corresponde a um alto teor de água, pois neste ano ocorreu uma maior precipitação, enchendo todo o reservatório, já os valores de NDWI em 2016 foram baixos, devido à baixa precipitação, desta forma, não havendo o aumento do volume considerável. O NDWI pode ser usado para detectar e monitorar a presença de água, sendo uma excelente ferramenta para auxiliar órgão fiscalizadores de recursos hídricos através do monitoramento de rios, lagos e reservatórios das regiões bem como é o caso na região Nordeste.

Palavras-chave: Recursos hídricos; Geoprocessamento; Sensoriamento remoto; Semi-árido.

\footnotetext{
*Autor para correspondência

Recebido para publicação em 15/01/2017; aprovado em 10/03/2017

${ }^{1}$ Tecnóloga em Geoprocessamento, Mestranda em Ciências Florestais, Universidade Federal de Campina Grande, Patos; (83) 98825-8975,

denizegeo16@gmail.com

${ }^{2}$ Administrador, Especialista em Gestão da Qualidade e Produtividade, Mestrando em Sistemas Agroindustriais, Instituto Federal de Educação, Ciência e

Tecnologia, danilodemas@gmail.com

${ }^{3}$ Engenheiro Florestal, Mestre em Ciências Florestais, Universidade Federal de Campina Grande, ewerton.engflorest@gmail.com

${ }^{4}$ Bióloga, Mestre em Zootecnia , Universidade Federal de Campina Grande, claudia22leite@ gmail.com

${ }^{5}$ Engenheira Florestal. Pós graduanda em Ciências Florestais pela Universidade Federal de Campina Grande. E-mail: talyttaengflorest@hotmail.com

${ }^{6}$ Engenheira Florestal, Mestre em Zootecnia e Doutora em Agronomia, Universidade Federal de Campina Grande, ivobakke@ gmail.com
} 


\section{INTRODUCTION}

The northeastern region of Brazil occupies $18.27 \%$ of its total territory, in which there is a semi-arid area of 969,589 $\mathrm{km}^{2}$. It is a populated area accounting for $12 \%$ of the Brazilian population (23 million of people). At this semi-arid area, 962,857 $\mathrm{km}^{2}$ lies within a region called "Polígono das Secas" (Drought Polygon), characterized by rainfall irregularity, high temperatures, and dry climate (IBGE, 2010; MMA, 2003).

The rainy season irregularly concentrates in the first four months of the year, and high evaporation occurs during the last eight months of the year. Mean temperatures are $28^{\circ} \mathrm{C}$ with practically no variation throughout the year (KOEPPEN, 1996; ARAÚJO FILHO et al., 1995). There is a trend for periods of extreme droughts, and although rare, there are large floods (MARENGO, 2006). The shallow soils of the region have $70 \%$ of crystalline rocks and show higher evaporation rates (MALVEZZI, 2007). The variations of precipitation along time and space are among the features responsible for the water scarcity in the region.

The population and economic growth of the area have demanded a massive use of natural resources, mainly the water resources for urban and rural supplies. However, the improper management of water resources results in water scarcity and reduced volumes of reservoirs (MANASSÉS, et al., 2011).

Natural resources and the environment are in constant changing because of human activities. Temporal and spatial analyses are necessary to understand the extent of these changes, and the use of satellite images becomes the most efficient way to monitor and model phenomena such as the intensity of droughts in semi-arid regions of northeastern Brazil.

The use of geoprocessing tools and remote sensing techniques to support hydrological studies, as well as the Geographic Information Systems (GIS), have been widely adopted due to the efficient generation of data on water resources. Currently, the use of satellite images for mapping and monitoring of reservoirs, canals, and small lakes, based on the reflectance values of their bands, helps in the design and assessment of water bodies contributing to a better management plan for water resources (JACKSON et al., 2004).

The use of band equations results in radiometric indices applied to the detection of the presence of water, vegetation, and soil, such as the normalized difference index (NDVI), which allows the identification of vegetation presence using near-infrared (NIR) and red bands. The NDWI is an index derived from the NDVI in which the green band replaces the red band. According to McFeeters (1996), it is possible to obtain parameters that detect and separate targets from different materials such as water, vegetation, and exposed soils using green and medium infrared (NIR) bands.

Some authors use the near-infrared (NIR) and medium waive-infrared bands (SWIR) to calculate the NDWI, where the influence of photosynthesis and suspended sediments in the water bodies are highlighted. The near-infrared (NIR) has a greater range in the leaves and the shortwaves (SWIR) where the water content influences the reflectance (GAO, 1996; CECCATO et al., 2001). This study deals with the monitoring of small water bodies using the most applied index proposed by McFeeters (1996).
The NDWI index is a method to analyze data of water resources, as well as to delineate water features present in the environment with satellite images, allowing the monitoring through their shapes.

Considering the long drought from last few years in northeastern Brazil, this work uses the NDWI radiometric index to analysis the reduction of the water surface area during the dry periods (November 2009 and December 2016) at Capoeira Reservoir, Paraíba, Brazil.

\section{MATERIAL AND METHODS}

The Capoeira Reservoir (Figure 1) lies on the mountain ranges of Mãe D'Água region, semi-arid of Paraíba, Brazil, and was built through the damming of Rio da Cruz, a typical intermittent river of semi-arid.

Capoeira Reservoir belongs to the Espinharas watershed. The reservoir lies on the geographical coordinates of $7^{\circ} 25^{\prime} 7.63^{\prime \prime}-7^{\circ} 6^{\prime} 34.36^{\prime \prime S}$ and 37 $31^{\prime} 4.33^{\prime \prime}-37^{\circ} 16^{\prime} 27.29^{\prime \prime} \mathrm{W}$, and provides water to cities and rural areas of Mãe d'Água, Santa Terezinha, São José do Bonfim, and Patos.

Figure 1. Location of the Capoeira Reservoir, Mãe d'Água Municipality, Paraíba, Brazil

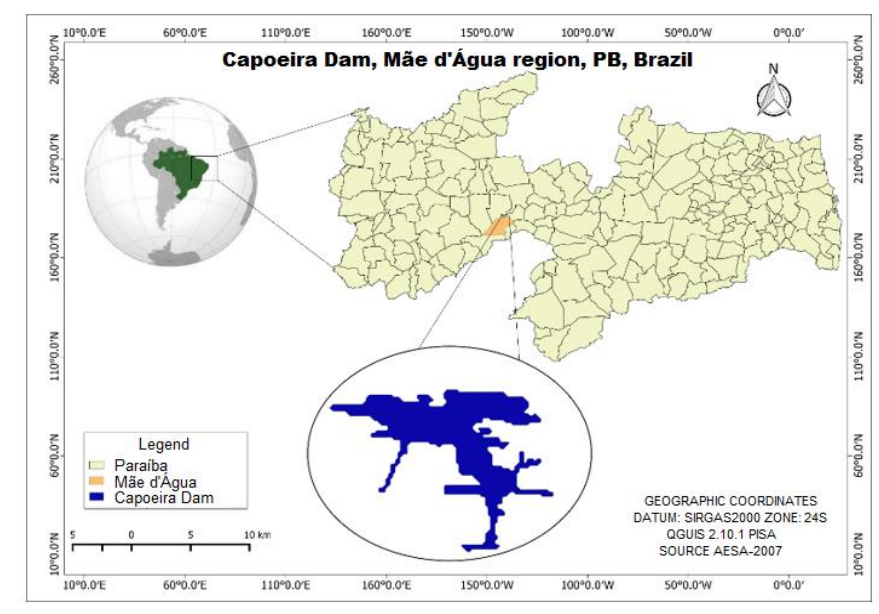

Source: Author (2016).

The climate is tropical semi-arid with summer rains (Bsh) at low altitude. Mean annual precipitation is $743 \mathrm{~mm}$, with most rains occurring from January to April, and an average temperature is $28^{\circ} \mathrm{C}$. The predominant vegetation comprises the hyper-xerophilic Caatinga, an open arborealshrubby forest (KOEPPEN, 1996; ARAÚJO FILHO et al., 1995).

The methodological procedures comprised four steps. First, we surveyed bibliographic and cartographic data of the studied area. Second, we obtained and selected images to preprocess and radiometric calibration according to the equation (1), which consists of the digital number (ND) conversion of each pixel of the image into spectral monochromatic radiance (MARKHAM; BAKER, 1987). Third, we processed of the images. Fourth, we used a Garmin Etrex GPS 30x to collect points to compare years and identify the absence and presence of water.

$$
\mathrm{L}^{\wedge}=\mathrm{ai}+((\mathrm{Lmin}-\mathrm{Lmax}) / 255) * \mathrm{nd}
$$

On what: $\mathrm{L}^{\wedge}$ is the apparent spectral radiance in a given band, Lmax and Lmin are the maximum and minimum 
radiance for the sensor and band, nd the digital number of the image in each band. The georeferencing of the image was based on known points. We used the first order polynomial as interpolator and the nearest neighbor as resampling method.

For this study, we used images from the drought period of 2009 (November) and 2016 (December), from the Landsat $5 \mathrm{TM}$ and 8 Oli, respectively. The images were obtained from the United States Geological Survey website (USGS) and georeferenced with a GLS image of the Landsat 5 TM, available from the Instituto de Pesquisas Espaciais (INPE). We generated a buffer of $2 \mathrm{~km}$, that is, a polygon with the purpose of expanding the area of influence around the Capoeira Reservoir.

We used the method of McFeeters (1996) that has the same reasoning and operations of bands of the normalized difference of vegetation index (NDVI). The bands GREEN and near-infrared (NIR) highlight water bodies and eliminates the influence of soil and vegetation. According to equation (2).

\section{NDWI $=($ GREEN-NIR $) /($ GREEN+NIR $)$}

(eq. 2)

The bands 2 and 4 correspond to green (GREEN) and near infrared (NIR) of Landsat 5 TM, while bands 3 and 5 correspond to green (GREEN) and near infrared (NIR) of Landsat 8 (OLI). The values of the index range from -1 to 1 , if NDWI $\geq 0$ there is the presence of water, if NDWI $\leq 0$, there is no water (MCFEETERS, 1996).

We used the UTM (Universal Transverse Mercator) coordinates to achieve the desired precision, starting with the IBGE cartographic base (vector files), in a scale of 1:250,000, from the South American Datum SAD69. After that, we converted the data to Datum SIRGAS2000, UTM Zone 24S. The analysis of processing, manipulation of the data, and layout of the maps were carried out in the geographic information systems (GIS), QGIS 2.10.1, an open source licensed software.

\section{RESULTS AND DISCUSSION}

In 2009, the water volume of Capoeira Reservoir reached the maximum capacity of $53,450,000 \mathrm{~m}^{3}$, due to the torrential rains that occurred in the region during that year. According to residents, in 2009, at the region, most of the reservoirs overflowed. Currently, the Capoeira Reservoir has $9,303,269 \mathrm{~m}^{3}$ (17.4\% of its capacity) (Figure 2) because of the low precipitation of the previous years. According to AESA (2016), the semi-arid of Brazil has faced the greatest drought of the last 20 years. Since 2010, the rainfall records have declined, and the population is under risk of lack of water supply. The population growth increases water consumption and the lack of planning have increased the problem. However, the population has not yet become aware of the need to change for a rational use of water.
Figure 2. Variation of water volume in the last years of Capoeira Reservoir, Paraíba, Brazil

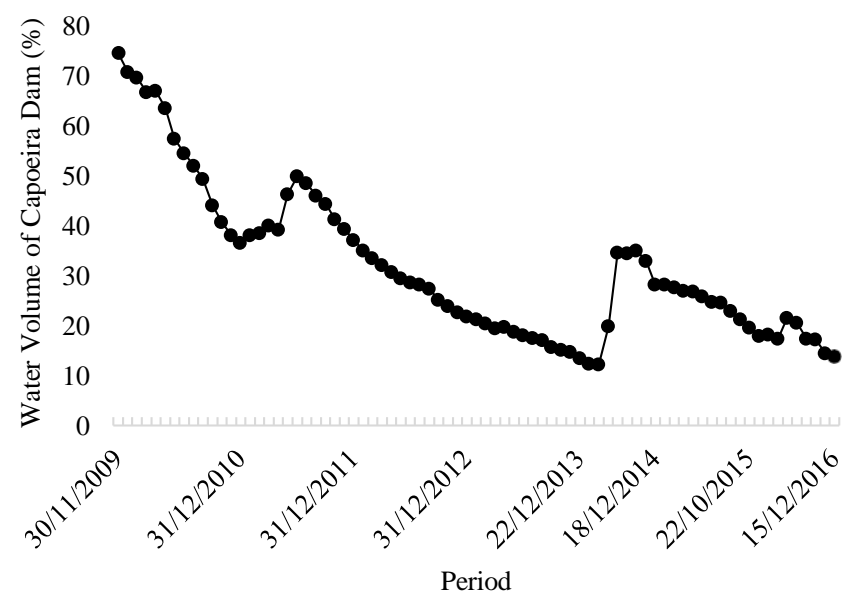

Source: AESA (2016)

NDWI has been shown to be useful for the monitoring of drought susceptible regions (Ceccato et al., 2002). During the dry season, plants lose their leaves to avoid loss of water by evapotranspiration, which is a characteristic of the semiarid region.

NDWI values are dimensionless and vary between -1 and +1 , depending on the water content of the leaf. Figure 4 shows the comparison of the dry period of 2009 (November) and 2016 (December). Positive values mean the presence of water, negative and zero values mean the presence of soil and vegetation.

The highest values of NDWI were found during 2009 (0.14), due to the intense rainfall caused by the La Niña phenomenon. According to INPE, in 2009, La Niña is an opposite phenomenon to El Niño, which is an abnormal cooling of the surface waters of the Tropical Pacific Ocean. For semi-arid regions, irregularities of intense droughts occur during El Niño years while intense rainy periods occur during La Niña. According to Alencar, et al. (2007), the El Nino event in the northeastern Brazil causes severe drought and significant losses in agriculture. In the year 2016, the highest NDWI values were -0.27 , indicating lower water volumes than in 2009 (Figure 4).

The Point A1 shows the difference between the years 2009 and 2016. During 2009 the point was covered by water while at 2016 was used for grazing by animals (Figure 3).

Figure 3. Point showing the absence of water in the year of 2016 in the month of December in Capoeira Reservoir, Mãe D'água region, Paraíba, Brazil

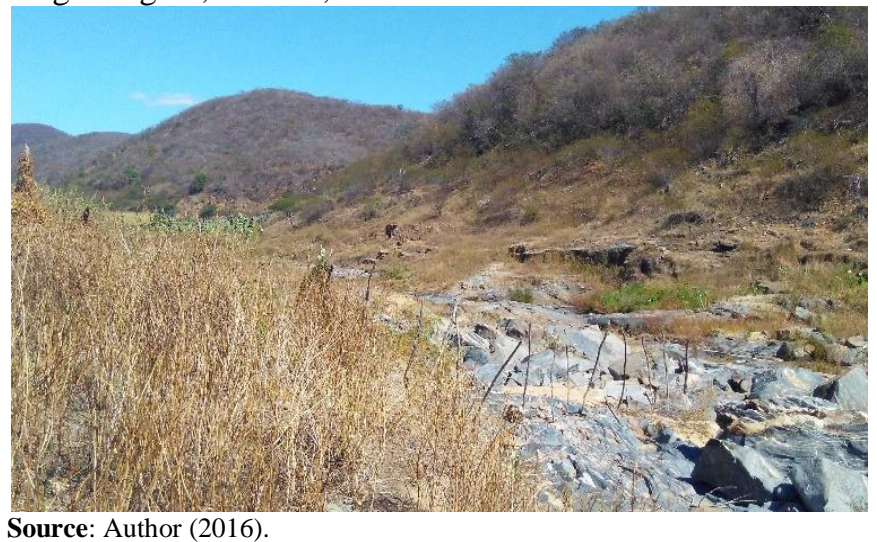


Figure 4. Normalized Difference Water Index - NDWI of Capoeira Reservoir, Mãe D'água region, in the dry period of 2009 (November) and 2016 (December).

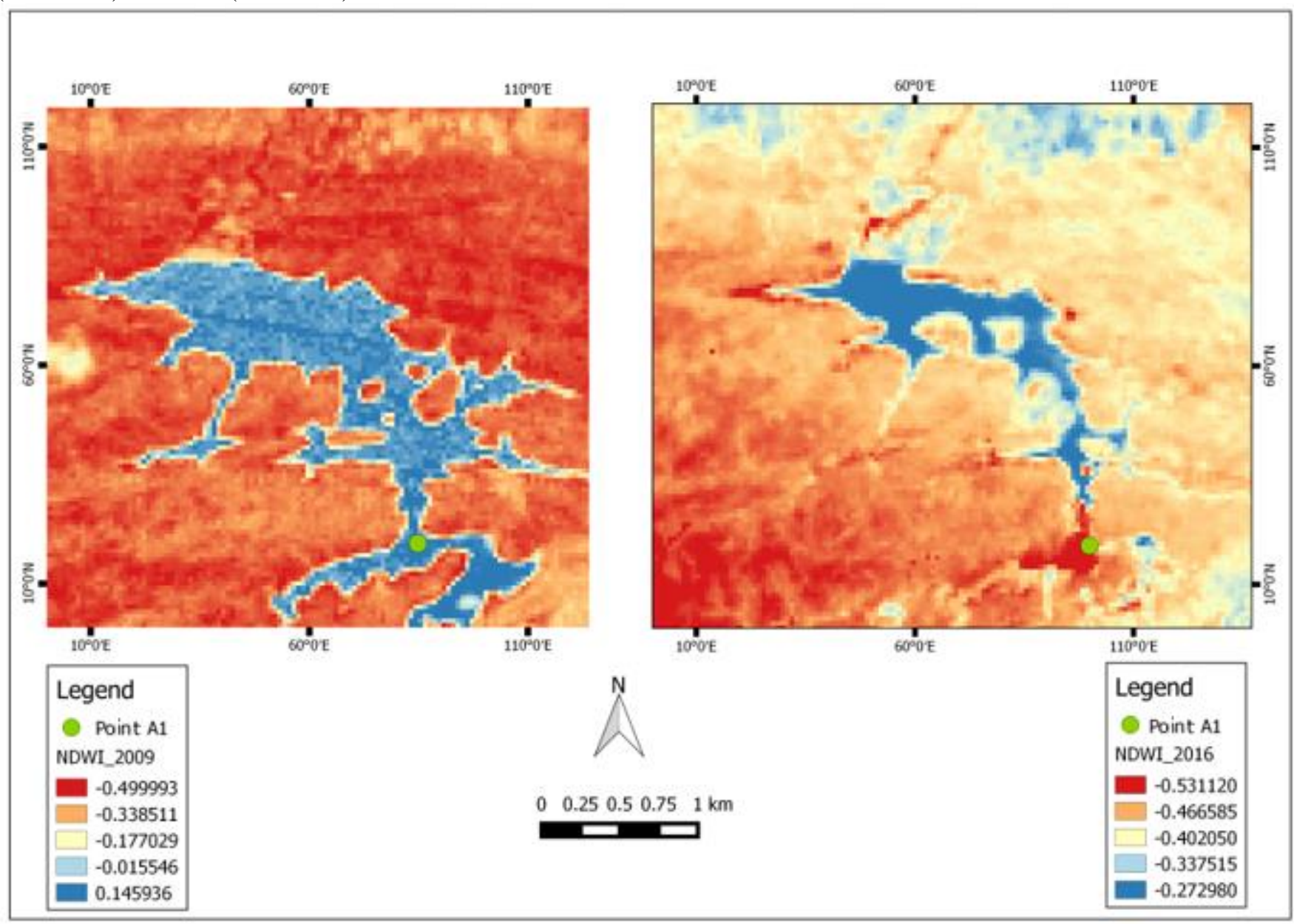

Source: Author (2016).

\section{CONCLUSIONS}

NDWI can be applied to delineate the water mirrors in reservoirs as it eliminates the interference of vegetation and soil simultaneously. The use of QGIS software 2.10.1 PISA, the Landsat 8 satellite (OLI / TIRS), and remote sensing techniques proved to be an efficient procedure to mapping the water volume in reservoirs. As a free-charge multi-platform, remote sense analysis might complement the information collected in the field by the governmental agencies and professionals and may assist in the planning and management of water resources.

\section{REFERENCES}

AESA. Agência Executiva de Gestão das Águas do Estado da Paraíba, 2009.

Disponível em:<http://www.aesa.pb.gov.br/geoprocessamento/geoportal/ mapas.html>. Acessado em 13 de Outubro de 2016.

ALENCAR, M. L. S. de; BARBOSA, M. P.; SOUSA, R. F. de. Efeitos do El Niño de 1997/1998 na produção agropecuária na bacia do Rio Sucuru - Cariri Paraibano. Revista Caminhos de Geografia, Uberlândia v. 8, n. 24, 2007

ARAÚJO FILHO, J. A.; SOUSA, F. B.; CARVALHO, F. C. Pastagens no semiárido: Pesquisa para o desenvolvimento sustentável. In: Simpósio Sobre Pastagens nos Ecossistemas Brasileiros, 32,1995, Brasília. Anais... Brasília: SBZ, 1995. p. 63-75.

CECCATO, P., FlASSE, S., and GREGOIRE, J.M. Designing a spectral index to estimate vegetation water content from remote sensing data: Part 2. Validation and applications. Remote Sensing of Environment 82: 198-207, 2002.

FERREIRA, A. B.; FILHO, W. P. Avaliação da Reflectância Espectral de Corpos D'água em Santa Maria-RS por Meio de Espectrorradiometria de Campo. Revista eletrônica do Curso de Geografia - Campus Jataí/GO - UFG. Site: www2.jatai.ufg.br/ojs/index.php/geoambiente. N.13 | juldez/2009.

GAO, B. C. NDWI: A Normalized Difference Water Index for remote sensing of vegetation liquid water from space. Remote Sensing of Environment, v.58, p.257-266, 1996.

IBGE. Instituto Brasileiro Geográfico e Estatístico. 2010. Disponível em: <http://www.ibge.gov.br>, Acessado em: 05 de Março de 2016.

INPE. Instituto Nacional de Pesquisas Espaciais. 1999. PRODES. Disponível em: 
http://www.dgi.inpe.br/siteDgi/portugues/index.php> Acesso em: 26.de Junho de 2016.

JACKSON, T. J.; CHENB, D.; COSHA, M.; LIA, F.; ANDERSONC, M.; WALTHALLA, C.; DORIASWAMYA, P.; HUNTA, R. Vegetation water content mapping using Landsat data derived normalized difference water index for corn and soybeans. Remote Sensing of Environment. v.92, p. 475-482, 2004.

KOEPPEN, W. Tradução: Corrêa, A.C.B. Sistema Geográfico dos Climas. Notas e Comunicado de Geografia - Série B: Textos Didáticos $\mathrm{n}^{\mathbf{0}}$ 13. Ed. Universitária - UFPE, Departamento de Ciências Geográficas, UFPE, p.31, 1996

MALVEZZI, R. Semiárido- Uma Visão Holística. - Brasília: Confea, 2007.2 140p.Disponivel: <http://www2.ufersa.edu.br/portal/view/uploads/setores/241/s emi\%20arido.pdf> Acesso:28 de Junho de 2016

MANASSÉS, M. D. S.; MEDEIROS, P. R. F.; SILVA, E. F. D. F. Recursos hídricos em regiões áridas e semiáridas. Campina Grande: Instituto Nacional do Semiárido, 2011.

MARENGO, J. A. Mudanças climáticas globais e seus efeitos sobre a biodiversidade: caracterização do clima atual e definição das alterações climáticas para o território brasileiro ao longo do século XXI. Brasília, DF: MMA, 2006. 202 p. il

MARKHAM, B. L.; BARKER, J. B. Thematic mapper band pass solar exoatmospherical irradiances. International Journal of Remote Sensing. v. 8, n. 3, p. 517-523, 1987

MCFEETERS, S. K. The use of the Normalized Difference Water Index (NDWI) in the delineation of open water features. International Journal of Remote Sensing, v.17, n.7, p.1425-1432, 1996.

MMA. Ministério do Meio Ambiente, 2003. Disponível em:<http://www.mma.gov.br/biomas/caatinga>. Acessado em: 05 de Junho de 2016.

NAMIKAWA, L. M. Imagens Landsat 8 para Monitoramento de Volume de Água em Reservatórios: Estudo de Caso nas Barragens Jaguari e Jacareí do Sistema Cantareira, p 4828 4835. Anais... XVII Simpósio Brasileiro de Sensoriamento Remoto - SBSR, João Pessoa-PB, INPE, 2015.

USGS. Landsat Missions: Using the USGS Landsat8 Product. U.S. Department of the Interior - U.S. Geological Survey NASA, 2016. Site <http://landsat.usgs.gov/Landsat8_Using_Product.php>. Acessado em: 20 de Agosto de 2016. 